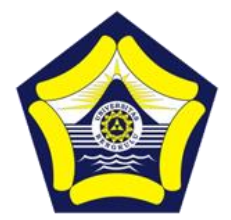

\title{
The Development of E-Book on Flood Mitigation to Increase Students' Metacognitive Skill
}

\author{
Kiki Lucky Novaliaa, ${ }^{1 *}$, Bhakti Karyadi ${ }^{1}$, M. Farid ${ }^{2}$ \\ ${ }^{1}$ Graduate School of Science Education, University of Bengkulu \\ ${ }^{2}$ Department of Physics, University of Bengkulu \\ Email: kikiluckynovalia27@gmail.com
}

DOI: https://doi.org/10.33369/bjset.1.2.47-54

\begin{abstract}
The aims of this study were to analyse the flood mitigation in the Musi Sub Watershed of Ujan Mas Kepahiang Sub-District and to describe the design, characteristic and feasibility of the physics e-book on integrated fluid material of developed disaster mitigation. In addition, the results of the e-book application of the integrated physics material on flood disaster mitigation are analysed in improving students' HOTS on the dimension of metacognitive knowledge. This study applies a 4-D development model consisting of four stages which are Define, Design, Develop, and Disseminate. The analysis results of observations of flood-affected areas using a spatial zoning approach based on elevation, distance from the river, topography of the area, and the use of GIS applications are used to create flood-prone maps. The results of the flood mitigation study are used to design the contents of the fluid physics e-book. Characteristics of developed e-book include missions, competencies, basic theories, basic activities, material resources, and assessment characters. The sample used as a trial for implementing the e-book was the students at SMK 1 Rejang Lebong and selected by using the Purposive Sampling Technique. According to the expert validation, the e-book is highly feasible to be applied as teacher's teaching material with an average percentage score of $95.86 \%$. Students' HOTS ability on the metacognitive dimension of classical knowledge is $6.67 \%$ very good; $26.66 \%$ good; $46.67 \%$ adequate; $13.33 \%$ less; and $6.67 \%$ very less. The e-book of integrated fluid on mitigation flood for Class X SMA/MAK in the concentration subject of Technology and Engineering was able to improve students' metacognitive abilities with an $\mathrm{N}$ gain value of 0.65 (moderate).
\end{abstract}

Keywords: Physics E-Book, Fluid Material, Flood Mitigation, Metacognitive Ability.

\section{INTRODUCTION}

Currently in the $21^{\text {st }}$ century, teachers are required to be able to equip students with recent skills for competing globally. Teachers can develop $21^{\text {st }}$ century skills in students by designing a learning process which oriented to Higher Order Thinking Skills (HOTS). Higher-order thinking skills are complex thought processes in breaking down material, making conclusions, building representations, analysing and building relationships by involving the most basic mental activities (Supriano, 2019). When students are accustomed to think at a high level, they will learn more deeply to collaborate with various information, ideas, and facts and also to obtain new knowledge to arrive at conclusions or interpretations (Newman, 2005). According to King et al (2015), HOTS is critical, logical, reflective, creative and metacognitive thinking. Higher level thinking skills on the dimension of metacognitive knowledge is a higher level thinking ability to be able to control one's cognitive processes in learning (Livingston, 1997). Students who have metacognitive skills will have good self-regulation, so that it will affect the learning outcomes (Norman and Furnes, 2016). 
An approach that can be used to develop students' HOTS in learning is the STEM approach. Learning with the STEM approach trains students to think critical, creative, collaborative and communicative so that they can achieve the skills required indirectly in the $21^{\text {st }}$ century. In learning with the STEM approach students can integrate aspects of science, technology, engineering and mathematics to solve real-world problems. The approach of these four aspects is a matching pair between problem-based learning and problems that occur in the real world (Torlakson, 2014).

One problem that occurs around the students is flood disaster. Flooding simultaneously in Bengkulu Province in April 2019 was considered as the worst flooding disaster in decades. One of the areas that affected by flooding is in the Musi Hulu Sub-watershed, Ujan Mas Kepahiang Subdistrict. Flood mitigation is needed to face the possibility of a repeat of the flood disaster. According to the Law No. 24/2007, mitigation is a series of efforts to reduce disaster risks, both through physical development and raising awareness and also capacity to face the threat of disaster. Mitigation can be done structurally (physical development) and non-structural (education). The efforts to mitigate flood disasters in education can be done by integrating flood material into the physics learning of fluid material. Through the STEM approach, the learning activities carried out can direct students to solve problems about flood disasters. The STEM approach can direct students to go through the process of cognitive complexity from factual, procedural, and conceptual to metacognitive knowledge. Metacognition in the 2013 curriculum is the ability to link knowledge with another. HOTS on the metacognitive dimension becomes an important instrument as a first step in forming knowledge and realizing the character of students who have competency in preparedness for flood disasters. Therefore, we develop SMK/MAK physics teaching materials on fluid materials that are integrated with flood disaster mitigation which are packaged in the form of electronic books (e-book). E-book can display multimedia files in the form of audio and video that can enrich the contents of the book, making it more interesting, and easier to disseminate and also share information.

The study, therefore, can be formulated into some specific research questions including: 1) What are the results of the analysis of the flood disaster mitigation study in the Musi Sub Watershed of Ujan Mas Kepahiang Sub-district? 2) How are the designs, characteristics and feasibility of the ebook of integrated physics material on flood disaster mitigation for class X SMK/MAK in the concentration subject of Technology and Engineering? 3) How does the increase of students' HOTS on the dimension of metacognitive knowledge after the application of physics e-book on integrated fluid material of flood mitigation?

\section{RESEARCH METHODS}

The study was conducted on December 2019 to May 2020. For flood disaster research, it was carried out in some villages such as Cugung Lalang, Air Hitam, Tanjung Alam, and Suro Bali in the Musi Sub Watershed area, Ujan Mas Kepahiang Sub-District. The trial product of e-book was applied on a limited basis, more specifically for grade X students of SMK Negeri 1 Rejang Lebong. The subjects in this study were 15 students of class X SMK 1 Rejang Lebong and were selected by using the purposive sampling, which is a technique with certain considerations (Sugiyono, 2012). The development of e-book was based on the results of literature studies and flood mitigation studies in the Musi Sub Watershed area, Ujan Mas Kepahiang Sub-District. The research and development was carried out based on the 4-D model development procedure, including Define, Design, Develop and Disseminate (Thiagarajan, 1974).

At the define stage, an analysis was carried out to determine and define the needs in the development of e-book, including; (1) teaching materials; (2) basic competence; (3) indicators of achieving competence; (4) fluid material; and (5) analysis of data requirements for conducting flood mitigation studies. The next stage was to design the framework and contents of e-book, the validation instrument of e-book, and the test instruments of HOTS that were used in the e-book trial. At this stage, the research data for flood mitigation studies were also used to develop the contents of e-book. 
Mapping the potential for regional flooding was done through a spatial zoning approach based on elevation, distance from the river, and topography. Coordinate and elevation data were obtained directly in the field using the Garmin GPS and processed using Google Earth application. The observed data provided the maximum and minimum number of scores used to calculate the range of potential flood classes. The results were then divided into 3 range classes of potential flood classifications including low, medium, and high. Overlay between regional administration maps and observational data was done to create a Flood Hazard Map using Software of ArcGIS 10.2. Information on the results of the mitigation study analysis was used to design the contents of the ebook, consisting on the material, student's worksheets, and HOTS questions for students.

Furthermore, at the develop stage, validation was carried out by material and media experts to determine the feasibility and pass the revisions needed based on expert advice on the developed ebook. In addition to this stage, a limited testing was carried out to determine the effectiveness of ebook in improving students' HOTS on the dimension of metacognitive knowledge. Finally, at the disseminate stage, teaching material product that had been packaged in the form of e-book was distributed more widely using websites that could be accessed so that easier to disseminate and can be used by other teachers.

The data analysis technique used descriptive data qualitatively and quantitatively. After analysing the e-book, it was feasible if the assessment of lecturers and teachers gave a feasibility value of $\geq 61 \%$ (Riduwan, 2013). To measure the increase of students' HOTS on the dimension of metacognitive knowledge on the application of developed e-book, it was done by comparing the scores of pre-test and post-test on the student learning outcomes. The results were then analysed using the N-Gain Test, which according to Hake it could provide a general description of the increase in scores of learning outcomes between before and after the implementation of the method.

\section{RESULTS AND DISCUSSION}

The research and development was carried out to produce teaching material products for physics subjects. It was in the form of E-book of Fluid and Flood Disaster Mitigation for Class X SMA/MAK in the concentration subject of Technology and Engineering. Teachers can utilize this ebook as an alternative model for integrating flood disaster mitigation in fluid materials. The development of e-book is based on the results of literature studies and flood mitigation studies in the Musi Sub Watershed area, Ujan Mas Kepahiang Sub-District. The factors causing flooding in villages around the Musi Sub-watershed area are the meteorological conditions and topography of the region. Average rainfall that occurs during floods is $597 \mathrm{~mm} /$ day (extreme rain), as presented on Figure 1.

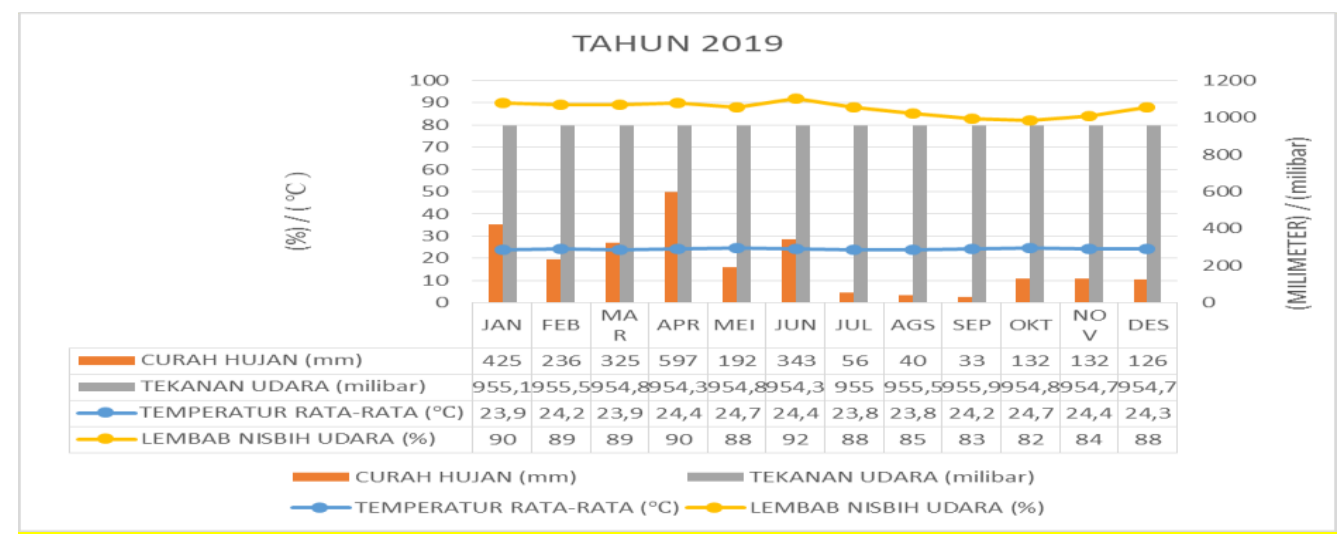

Figure 1. Meteorological Data of Ujan Mas Kepahiang Sub-District 2019 Source: Meteorology, Climatology and Geophysics Agency (BMKG) of Kepahiang 
Curah hujan: Rainfall (mm)

Tekanan udara: Air pressure (milibar)

Temperature rata-rata: Average temperature $\left({ }^{\circ} \mathrm{C}\right)$

Lembab nisbih udara: Moisturizing air (\%)

Flooding is also caused by river sedimentation that occurred due to erosion and forest destruction in the Musi Hulu Sub-watershed area of 1,602 Ha. Village areas that were affected by flooding were mostly in the slope class $(0-8) \%$ or called as flat land. The overlay between the administrative map of the area and the observation data of the flood-affected area to create a Flood Hazard Map was conducted by using the software of ArcGIS 10.2. The map of flood vulnerability in villages in the Musi Hulu Sub-watershed area in Ujan Mas Kepahiang Sub-District is as follows:

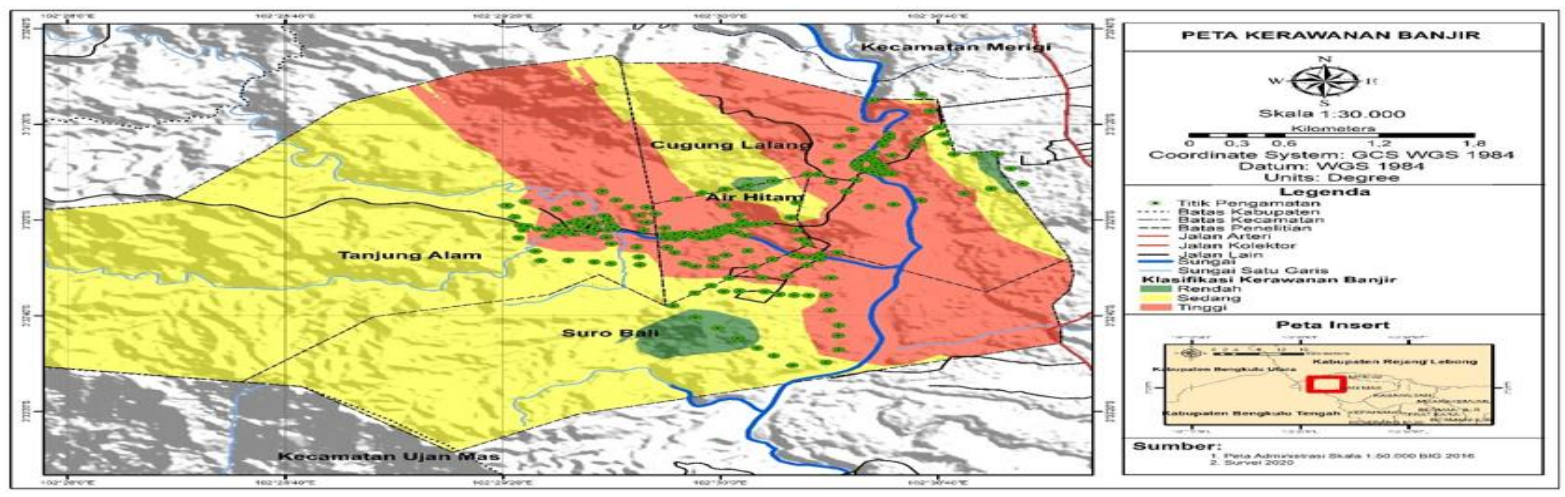

Figure 2. Map of Village Flood Hazard in Musi Hulu Sub Watershed Area, Ujan Mas Kepahiang Sub-District

On the map shown on Figure 2, it can be visually seen that the red-colored areas are areas that have high flood hazard, yellow areas are areas that have moderate flood hazard, and green areas are areas that have low flood hazard. The mapping of flood-prone areas can be utilized as an effort of the flood disaster early warning system. It is the initial step of preparedness in minimizing or reducing losses due to flood disasters. Information on the results of the mitigation study analysis is used to develop the contents of the e-book.

Basic Competencies (KD) that are relevant for integration in flood disaster mitigation efforts are based on the results of the 2013 revised edition syllabus curriculum analysis in group $\mathrm{C} 1$. The Basic Field of Physics Subjects for the Technology and Engineering group are KD 3.8 to apply laws relating to static and dynamic fluids, and KD 4.8 to conduct simple experiments relating to static and dynamic fluid laws. The design of e-book in general consists of four main parts, (1) Introduction; (2) Fluid Material Integrated Flood Mitigation; (3) Strategy for Integration of Flood Mitigation in Fluid Material in Physics Learning; and (4) Learning Assessment. E-book is further published in two versions of pdf and flip book which can be accessed online. Characteristics of developed e-book include missions, competencies, basic theories, basic activities, material resources, and characters assessment are shown in Table 1.

Table 1. E-book Characteristics on Fluid and Flood Mitigation

\begin{tabular}{|c|c|c|}
\hline No & $\begin{array}{c}\text { Characteristics of } \\
\text { E-Book }\end{array}$ & Remarks \\
\hline
\end{tabular}




\begin{tabular}{|c|c|c|}
\hline 1 & Mission & $\begin{array}{l}\text { To develop fluid e-book and flood disaster mitigation for class } X \\
\text { SMK/MAK in the concentration subject of Technology and } \\
\text { Engineering, which is sourced from natural phenomena around students, } \\
\text { which is flooding in villages in the Musi Hulu Sub-watershed area, Ujan } \\
\text { Mas Kepahiang Sub-District. The application of this e-book can be used } \\
\text { as one of the integrated models for flood disaster mitigation in fluid } \\
\text { materials. }\end{array}$ \\
\hline 2 & Competencies & $\begin{array}{l}\text { Mentioning phenomena related to fluids in daily life. } \\
\text { Mentioning the properties of fluids. } \\
\text { Identifying differences in static and dynamic fluids and then describing } \\
\text { the quantities on static and dynamic fluids. } \\
\text { Understanding the concepts and laws of static and dynamic fluids. } \\
\text { Applying the concept of hydrostatic pressure, the principles of Pascal } \\
\text { Law, Archimedes Law, Continuity equations, and Bernoulli equations } \\
\text { in solving problems of daily life. } \\
\text { Connecting concepts and application of static and dynamic fluid laws } \\
\text { with flood contextual problems and flood mitigation efforts. } \\
\text { Analysing the relationship between the principle of the work of the Early } \\
\text { Warning System (EWS) simple flooding with static and dynamic fluid } \\
\text { laws. }\end{array}$ \\
\hline 3 & Basic Theory & $\begin{array}{l}\text { E-book fluid and flood disaster mitigation is one of the integrated } \\
\text { models of flood disaster mitigation in fluid material developed using the } \\
\text { STEMS approach. }\end{array}$ \\
\hline 4 & Basic Activities & $\begin{array}{l}\text { Integrated strategy of flood disaster mitigation in fluid materials in } \\
\text { learning activities uses five phases: reflection, research, discovery, } \\
\text { application, and communication. In each of these phases, the learning } \\
\text { activities arranged are directed to stimulate and develop students' HOTS } \\
\text { on the dimension of metacognitive knowledge, of which are planning, } \\
\text { monitoring, evaluating and revising. In the e-book, there is text } \\
\text { (material), videos, questions for students, as well as discussion sheets to } \\
\text { support this. }\end{array}$ \\
\hline 5 & Material Sources & $\begin{array}{l}\text { Sources of material come from literature studies and research data on } \\
\text { flood disaster mitigation studies in the Musi Hulu Sub-watershed, Ujan } \\
\text { Mas Kepahiang Sub-District. }\end{array}$ \\
\hline 6 & $\begin{array}{l}\text { Characteristics } \\
\text { Assessment }\end{array}$ & $\begin{array}{l}\text { Higher Order Thinking Skills (HOTS) on students' metacognitive } \\
\text { abilities are measured using an instrument in the form of } 8 \text { items that } \\
\text { have } 4 \text { metacognitive indicators, including planning, monitoring, } \\
\text { evaluating and revising. }\end{array}$ \\
\hline
\end{tabular}

(Source: Adapted from Johan, 2018)

The feasibility of e-book product is assessed based on the media and material aspects carried out by two media experts and three material experts. The developed e-book was valued feasible by media validators with a percentage score of $93.27 \%$ (very feasible criteria) and material validator with a percentage score of $98.44 \%$ (very feasible criteria). Overall, validation e-book obtained an average percentage of $95.86 \%$ with a very decent category. At the develop stage, the product 
development is also carried out based on the product revision that has been designed. Product revisions are based on suggestions from media and material validators.

The product trials were conducted on a small scale, using 15 students in class X of SMKN 1 Rejang Lebong as research subjects. A product trial was tested to determine the effectiveness of the application of e-book fluid and flood disaster mitigation in increasing students' HOTS on the dimension of metacognitive knowledge. Before the implementation of the e-book, there is conducted a pre-test for the students first. Pre-test is examined to determine the effectiveness of the implementation of e-book by comparing it with the results of the post-test given at the end of learning. Because the trial was taking place during the Covid-19 pandemic outbreak, the application of e-book was applied online via the WhatsApp (WA) group. HOTS Metacognitive development of students is measured using integrated strategies for flood disaster mitigation in fluid material in physics learning as contained in e-book. The learning process is divided into three learning units using stages according to syntax of the PjBL STEM model (Laboy-Rush, 2010). There are five phases in the learning activities, which are reflection, research, discovery, application, and communication. In each of these phases, organized learning activities are directed to develop students' HOTS on the metacognitive knowledge dimension, consisting of planning, monitoring, evaluating and revising. In learning activities, there is factual information both from text (material) and videos, questions, discussion sheets that encourage students to know, understand and relate flood problems and efforts to mitigate flood disasters with concepts of static and dynamic fluid laws. Learning activities are expected to help students understand the application concepts of static and dynamic fluid laws in flood mitigation efforts factually, conceptually, procedurally and metacognitively.

The percentage of students' HOTS ability on the metacognitive knowledge dimension after using the developed e-book is $6.67 \%$ very good; $26.66 \%$ good; $46.67 \%$ adequate; $13.33 \%$ less; and $6.67 \%$ very less. This percentage shows that assisted learning as a e-book- result of development in general can develop students' HOTS who refer to the metacognitive knowledge dimension (Brown, 2007), although there are still $13.33 \%$ of students in the poor category and $6.67 \%$ of students in the very poor category (Figure 3 ).

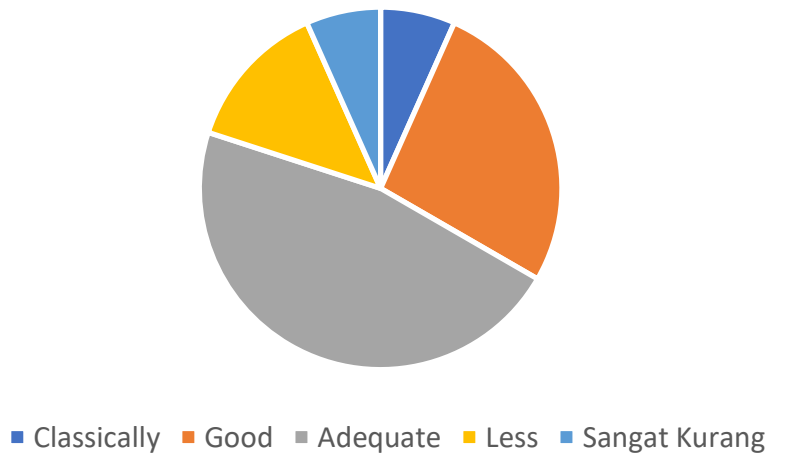

Figure 3. HOTS Percentage based on Students' Classical Metacognitive Knowledge Dimension

Students' HOTS indicators on metacognitive knowledge are measured by the results of the post-test, contained in the assessment questions that are planning, monitoring, evaluating and revising. Table 2 shows that the metacognitive indicators planning reach an average value of 84 (good), monitoring with a value of 70.67 (adequate), evaluating with a value of 64.00 (less), revising with a value of 81.33 (good).

Table 2. HOTS data based on Dimensions of Student' Metacognitive Knowledge

\begin{tabular}{|l|l|l|l|}
\hline No & Metacognitive Indicator & Value & Category \\
\hline
\end{tabular}




\begin{tabular}{|l|l|l|l|}
\hline 1 & Planning & 84.00 & Good \\
\hline 2 & Monitoring & 70.67 & Adequate \\
\hline 3 & Evaluating & 64.00 & Less \\
\hline 4 & Revising & 81.33 & Good \\
\hline
\end{tabular}

Based on the results of the assessment of students' HOTS shown on Table 3, the indicators Planning and Revising have good results, but the value of Monitoring is still in sufficient stage, even the value of Evaluating is still in the poor stage. In the taxonomy of learning according to Bloom, evaluation skills are at the highest level of cognitive thinking. Evaluation skills require careful thought in determining the value of something with various existing criteria. At the stage of evaluating, students are required to be able to connect other cognitive aspects in assessing facts or concepts. This might be the cause of learning activities can only be conducted via online because students must study at home during the Covid 19 global pandemic, which is in fact it should be running in face-to-face method. In learning activities which conducted online are still not able to stimulate students to develop the ability to synthesize and conduct evaluations. This stage should be achieved well if learning takes place actively and students become the center point. According to Sudjana (2006), students' activity can be seen in terms of: (1) participating in carrying out learning tasks; (2) asking other students or teachers if they do not understand the problems; (3) actively involved in problem solving; (4) trying to find various information needed for problem solving; (5) carrying out group discussions in accordance with the instructions of the teacher; (6) self-training in solving similar problems; (7) assessing the abilities and the results obtained; (8) using or applying the opportunity what is obtained in completing the task or problem faces. On the other side, teachers are difficult in monitoring directly the process in online learning. Online learning also tends to be one-way and students tend to be passive in the process of discussion, question, and answer. Students are also not accustomed to learning and training themselves independently in solving problems, and assessing their own abilities. In addition, teachers and students are not accustomed to online learning.

From the Meltzer gain criteria, an $\mathrm{N}$ gain value of 0.65 is obtained. Based on the results of the $\mathrm{N}$ Gain analysis, the criteria for students' learning outcomes using e-book fluid and flood disaster mitigation are moderate. Metacognitive can be called thinking about thinking, which is the ability to reflect information that is known and the circumstances that occur and the relationship between them. From the assessment of learning outcomes and completeness of learning outcomes, students are generally able to understand and relate information about concepts and laws of static and dynamic fluids in flood problems and flood disaster mitigation efforts in accordance with the contents of the e-book. However, students are still unable to reach the stage of synthesizing and evaluating well due to the limitations of online learning processes and activities.

\section{CONCLUSIONS}

The factors causing flooding in villages around the Musi Hulu Sub-watershed are the meteorological conditions and topography of the region. The average rainfall that occurs during floods is $597 \mathrm{~mm} /$ day which is considered as an extreme rain. Flooding is also caused by river sedimentation that occurred due to erosion and forest destruction in the Musi Hulu Sub-watershed area of 1,602 Ha. Village areas that were affected by flooding were mostly in the slope class (0-8)\% or flat land. Based on the mapping of flood-prone areas using a spatial zoning approach based on elevation, distance from the river, topography of the area and the use of GIS applications, the highest flood potential was found in most areas of Air Hitam Village, moderate potential in Tanjung Alam and Cugung Lalang Villages, low potential at Suro Village, Bali. The E-book product of Fluid and 
Flood Disaster Mitigation for Class X SMA/MAK in the concentration subject of Technological and Engineering has a design that is directed to stimulate and develop students' HOTS on the dimension of metacognitive knowledge.

The e-book generally consists of four parts, including Introduction, Integrated Fluid Materials on Flood Mitigation, Strategy of Flood Mitigation Integration in Fluid Material in Physics Learning, and Learning Assessment. E-book is published in two versions of pdf and flip book, which can be accessed online. Characteristics of developed e-book include missions, competencies, basic theories, basic activities, material resources, and characters assessment. The developed e-book was decided feasible by media validators with a percentage score of $93.27 \%$ (very feasible criteria) and material validator with a percentage score of $98.44 \%$ (very feasible criteria). Overall, e-book validation obtained an average percentage of $95.86 \%$ with a very decent category. E-book Fluid and Flood Mitigation for Class X SMA/MAK in the concentration subject of Technology and Engineering is able to increase students' HOTS on the dimension of metacognitive knowledge of Grade X students of SMKN 1 Rejang Lebong. The percentage of students' abilities on classical knowledge is at $6.67 \%$ very good; $26.66 \%$ good; $46.67 \%$ adequate; $13.33 \%$ less; and $6.67 \%$ very less. The result of the $\mathrm{N}$ Gain analysis shows that the criteria for the value of student learning outcomes using e-book fluid and flood disaster mitigation are moderate. Based on the average value of students, they are generally able to understand and relate information about concepts and laws of static and dynamic fluids in flood problems and efforts to mitigate flood disasters in accordance with the contents of the ebook. This shows that there is an increase in students' metacognitive abilities after learning using fluid e-book and flood disaster mitigation.

\section{REFERENCES}

Johan, Henny. (2018). Pengembangan Phenomena-Based Interactive Conceptual Instruction (PBICI) Pada Perkuliahan IPBA Untuk Meningkatkan Kemampuan Bernalar dan Sikap Spiritual Mahasiswa Calon Guru Fisika. Thesis. Bandung: Universitas Pendidikan Indonesia.

King, F.J., Goodson, L., and Rohani, F. (2015) Assessment and evaluation educational services program: Higher-order thinking skills. Washington, DC: A publication of the Educational Services Program.

Laboy-Rush, D. (2010) Integrated STEM education through project-based learning. www.learning.com/stem/whitepaper/ integrated-STEM-through Project-based-Learning.

Livingston, J.A. (1997) Metacognition: An Overview. (online) http://www.gse.buffalo.edu/fas/sh uell/CEP564/Metacog.html

Newman., Mark, J. (2005) Problem Based Learning: An Introducing and Overview of the Key Features of the Approach. JVME, 32 (1): 12-20.

Norman, E., and Furnes, B. (2016) The relationship between metacognitive experiences and learning: Is there a difference between digital and nondigital study media. Computers in Human Behavior, 54, 301-309. https://doi.org/http://dx.doi.org/10.1016/ j.chb.2015.07.043.

Riduwan. (2013) Skala Pengukuran Variabel Penelitian. Bandung: Alfabeta.

Sudjana, Nana. (2006) Dasar-dasar Proses Belajar Mengajar. Bandung: Sinar Baru Algensido Offset.

Sugiyono. (2012) Metode Penelitian Pendidikan (Pendekatan Kuantitatif, Kualitatif, dan R\&D). Bandung: Alfabeta.

Supriano (2019) Paket Unit Pembelajaran Mata Pelajaran IPA Energi Dan Perubahannya. Jakarta: Ditjen GTK Kemendikbud.

Thiagarajan, S., Semmel, D. S., and Semmel, M. I. (1974) Instructional for Training Teachers of Exceptional Children. Minnesota: Center for Innovation in Teaching the Handicapped.

Torlakson, T. (2014) Innovate: A Blueprint for Science, Technology, Engineering, and Mathematics in California Public Education. California: State Superintendent of Public Instruction. 